\title{
Recombinant Beta Thromboglobulin
}

National Cancer Institute

\section{Source}

National Cancer Institute. Recombinant Beta Thromboglobulin. NCI Thesaurus. Code C2325

A therapeutic analogue of an endogenous, platelet-specific protein that is a member of the alpha chemokine family. Beta thromboglobulin may be used as a marker for platelet activation. ( $\mathrm{NCl04)}$ 